\title{
Sistem Mitigasi Bencana Berbasis Masyarakat Di Pantai Muncar Kabupaten Banyuwangi
}

\section{Community-Based Disaster Mitigation System In Muncar Beach, Banyuwangi Regency}

\author{
Moh. Fahrurrozi ${ }^{1}$, R. Dravendy Marta Ishardhi ${ }^{2 *}$ \\ ${ }^{1}$ Program Studi Manajemen, Fakultas Ekonomi, Universitas 17 Agustus 1945 Banyuwangi \\ ${ }^{2}$ Progam Studi Ilmu Hukum, Fakultas Hukum Universitas 17 Agustus 1945 Banyuwangi \\ e-mail: ${ }^{* 1}$ fahrurrozy@untag-banyuwangi.ac.id
}

Submited: 22 June 2021 Revised: 05 July 2021 Accepted: 16 July 2021

Publish: 31 July 2021

\begin{abstract}
Abstrak
Pantai Muncar Kabupaten Banyuwangi merupakan wilayah dengan resiko bencana tinggi. Penanganan bencana berbasis masyarakat ini bakal jauh lebih efektif dibandingkan badan-badan formal bentukan negara. Namun juga tidak berarti lembaga formal itu tidak penting. Pendidikan, penyuluhan, dan penyadaran masyarakat merupakan salah kegiatan mitigasi bencana non struktur/non fisik. Penelitian ini bertujuan untuk menganalisis tingkat pengetahuan dan kesiapsiagaan masyarakat pesisir pantai Muncar Kabupaten Banyuwangi dalam menghadapi bencana, dan untuk mengetahui bagaimanakah sistem mitigasi bencana berbasis masyarakat di pantai Muncar Kabupaten Banyuwangi. Penelitian ini menggunakan metode kualitatif dengan jenis penelitian deskriptif kualitatif. Data diperoleh melalui observasi, wawancara mendalam dan dokumen. Subyek penelitian ini adalah tokoh masyarakat, nelayan dan masyarakat desa Kedungrejo Muncar. Adapun teknik analisis dalam penelitian ini bersifat induktif. Dalam penelitian ini analisis induktif yang digunakan adalah teknik analisis interaktif. Hasil penenilitian menunjukkan bahwa paradigma terhadap penanganan bencana ditingkat penduduk belum cukup banyak berubah dan masih dikaitkan dengan mitos. Pengetahuan dan kesadaran masyarakat pesisir tentang mitigasi bencana masih sangat rendah.
\end{abstract}

Kata kunci: Mitigasi, Bencana, Muncar, Banyuwangi

Abstract

Muncar Beach, Banyuwangi Regency is an area with high disaster risk. Community-based disaster management will be much more effective than formal agencies set up by the state. But it also does not mean that formal institutions are not important. Education, counseling, and public awareness are nonstructural/non-physical disaster mitigation activities. This study aims to analyze the level of knowledge and preparedness of coastal communities in Muncar, Banyuwangi Regency in dealing with disasters, and to find out how the community-based disaster mitigation system in Muncar Beach, Banyuwangi Regency is. This research uses qualitative methods with qualitative descriptive research. Data were obtained through observation, in-depth interviews, and documents. The subjects of this research are community leaders, fishermen, and the people of Kedungrejo Muncar Village. The analysis technique in this research is inductive. In this study, the inductive analysis used is an interactive analysis technique. The results show that the paradigm of disaster management at the population level has not changed much and is still associated with myths. Knowledge and awareness of coastal communities about disaster mitigation are still very low.

Keywords: Mitigation, Disaster, Muncar, Banyuwangi

\section{PENDAHULUAN}

Indonesia merupakan salah satu negara yang dikenal sebagai negara kepulauan (lebih dari 17.504) dan sebagai negara kedua yang memiliki garis pantai terpanjang yaitu \pm 95.181 kilometer (Kementerian Kelautan dan Perikanan, 2019). Sebagai bukti bahwa Indonesia merupakan negara maritim yakni pada umumnya pertumbuhan kota dan pemukiman terlekak di dekat sungai 
atau di pesisir pantai, seperti Surabaya, Jakarta, dan Semarang merupakan kota di tepi laut jawa (Jokowinarno, 2011). Sebagai negara maritim Indonesia memiliki kekayaan dan potensi sumberdaya perisir sangat besar dan kompetitif. Potensi ini jarang dimiliki oleh negara-nagara lain sebab biaya pemanfaatan relatif murah sehingga memperkuat kapasitas penawaran. Akan tetapi, letak georafis dan geologis indonesia dikelilingi tiga lempeng benua, antara lain benua eropa-asia, benua pasifik, serta benua indoaustralia. Yang mana hal ini menyebabkan indonesia berpotensi mengalami bencana alam, baik berupa badai atau angin topan, tsunami, gempa bumi, banjir, dan bencana alam lainnya (Jokowinarno, 2011).

Bencana alam merupakan fenomena alam yang tidak bisa diprediksi dan tidak bisa dihindari serta dapat menimbukan kerugian bagi masyarakat, baik kerugian materi maupun non materi (Murdiaty et al., 2020). Hampir semua pulau di indonesia pernah mengalami bencana alam dan intensitasnya cukup tinggi, seperti tsunami di flores tahun 1992, tsunami di Aceh tahun 2004, gempa di Nias tahun 2005, gempa di Yogyakarta tahun 2006, gempa di Sumatera Barat dan Bengkulu tahun 2007, gempa di Lombok tahun 2018, gempa dan tsunami di palu dan donggala tahun 2018, dan lainnya (Darsiharjo, 2005).

Kabupaten Banyuwangi sendiri pernah terjadi bencana gempa bumi dan tsunami pada tahun 1994 di daerah pesisir selatan, seperti di Pantai Plengkung, Pantai Pancer dan Rajegwesi. Pada saat itu Kabupaten Banyuwangi diterjang tsunami dengan ketinggian $13.9 \mathrm{~m}$ akibat gempa 7,2 SR pada kedalaman 33 km (Prayoga et al., 2017). Banyuwangi memiliki panjang pantai hingga 175kilometer dan hampir semuanya berpotens tsunami. Menurut data Indeks Resiko Bencana (2014) yang dirilis oleh BNPB di Jawa Timur, Banyuwangi menduduki peringkat 4 sebagai kota/kabupaten yang berisiko terkena bencana dengan kelas resiko tinggi setelah Lumajang, Malang dan Jember. Sementara di Indonesia, Kabupaten Banyuwangi menduduki peringkat 11 sebagai kota/kabupaten yang berisiko terkena bencana dengan multi ancaman (BNPB, 2014). Berdasarkan fakta tersebut, salah satu pilihan untuk membuat langkah-langkah antisipatif adalah melakukan kegiatan penyadaran tentang resiko hidup di 
daerah pesisir pantai, terutama pesisir pantai Banyuwangi.

Menurut Undang-undang Nomor 24 Tahun 2007 (2007) tentang penanggulangan bencana bahwa cakupan bencana cukup luas. Oleh karena itu dibutuhkan kerjasama yang baik antara lembaga-lembaga kebencanaan baik di pusat maupun di daerah. Lemabaga-lembaga tersebut harus bisa bekerjasama dan bergotongroyong dengan masyarakat di setiap (empat) lini tahapan. Empat tahapan tersebut ialah: pertama, kesiapsiagaan diantranya melakukan perencanaan siaga dan peringatan dini. Kedua, tanggap darurat melakukan kajian darurat, rencana operasional, bantuan darurat. Ketiga, pasca darurat melakukan pemulihan, rehabilitasi, penuntasan, pembangunan Kembali. Keempat, Pencegahan dan mitigasi atau penjinakan dapat secara simultan dilaksanakan dengan peran aktif masyarakat.

Dari keempat tahapan tersebut, yang paling mungkin melibatkan masyarakat adalah tahapan langkahlangkah pencegahan dan mitigasi. Penanganan bencana berbasis masyarakat ini, akan lebih efektif dibanding dengan lembaga-lembaga formal Negara (Priyowidodo, G., \& Luik, 2013). Tetapi bukan berarti lembaga formal tersebut tidak penting. Lembaga tersebut senantiasa mempunyai peran sebagai manifestasi kehadiran negara ketika masyarakat berada pada situasi dan kondisi kritis. Bahwa tidak dipungkiri setiap bencana membawa korban baik manusia maupun harta benda adalah fakta. Tetapi apapun jenis bencana, sebelum ia datang selalu ada pertanda. (Priyowidodo, G., \& Luik, 2013)

\section{Disinilah}

pentingnya mengetahui dan memahami secara benar dan akurat setiap pertanda yang datang. Maka tentu yang diperlukan adalah pengetahuan, kecakapan dan ketrampilan bagaimana masyarakat terutama di wilayah rawan bencana tersebut mempersiapkan langkahlangkah antisipatif kedatangan bencana tersebut. Dari uraian ini, tujuan penelitian ini adalah mengetahui tingkat pengetahuan dan kesiapsiagaan masyarakat pesisir pantai Muncar Kabupaten Banyuwangi dalam menghadapi bencana dan menentukan sistem mitigasi bencana berbasis masyarakat di pantai Muncar Kabupaten Banyuwangi.

\section{METODE PENELITIAN}


Jenis penelitian ini adalah penelitan deskriptif kualitatif yang memfokuskan pada kawasan pesisir pantai Muncar Desa Kedungrejo. Pengumpulan data dengan observasi langsung.

Penelitian ini yang diobservasi adalah lingkungan masyarakat di Desa Kedungrejo Pantai Muncar, kemampuan dan kesiapsiagaan masyarakat dalam menghadapi bencana, terutama bencana gelombang tsunami, mengingat pantai Muncar merupakan salah satu daerah yang berpotensi tsunami, sehingga masyarakat di Pantai Muncar itu perlu memiliki rasa tanggap dan tangguh bencana. Selanjutnya, (indept interviewing) dengan subyek penelitian ini adalah tokoh masyarakat Desa Kedungrejo Muncar, nelayan dan masyarakat desa.

Disisi lain, dalam penelitian ini peneliti juga menggunakan studi dokumen untuk pengumpulan data yang bersumber dari arsip dan dokumen yang ada hubungannya dengan penelitian ini, seperti majalah, koran, hasil penelitian, artikel dan buku-buku yang ada kaitannya permasalahan yang dikaji dalam penelitian ini. Sedangkan teknik yang digunakan dalam penentuan informan adalah snowball sampling.
Adapun teknik analisis dalam penelitian ini bersifat induktif yaitu teknik analisis yang tidak dimaksudkan untuk membuktikan suatu prediksi atau hipotesis penelitian, tetapi simpulan dan teori yang dihasilkan berbentuk dari data yang dikumpulkan. Dalam penelitian ini analisis induktif yang digunakan adalah teknik analisis interaktif.

\section{HASIL DAN PEMBAHASAN}

Jenis penelitian adalah penelitian deskriptif. Survey dilakukan terhadap 10 orang masyarakat pesisir di Desa Kedungrejo, kecamatan Muncar, Kabupaten Banyuwangi. Data dikumpulkan dengan mengobservasi dan menginterview koresponden. Data yang sudah terkumpul, dianalisis secara univariat untuk mendeskripsikan setiap item pertanyaan mengenai persepsi terhadap kesiapsiagaan bencana.

Hasil penelitian menunjukan bahwa $80 \%$ responden menjawab berserah diri kepada Tuhan dan pasrah jika sewaktu-waktu terjadi tsunami. Mereka beralasan bahwa bencana alam seperti tsunami dan gempa bumi tidak bisa diperkirakan kapan datangnya dan bisa menimpa siapa saja. Hal ini senada dengan hasil temuan Agustin (2014) tentang persepsi masyarakat kenagarian 
sumani tentang kesiapsiagaan bencana gempa bahwa masyarakat kenagarian sumani Kecamatan Koto X Koto Singkarak Kabupaten Solok Propinsi Sumbar. Menurut Badan Nasional Penanggulangan Bencana (2007) bahwa di tingkat penduduk belum banyak berubah tentang paradigma penanganan bencana alam. Secara umum mereka beranggapan bahwa bencana alam merupakan balasan dari Tuhan atas dosa-dosa yang telah diperbuat oleh manusia dan merupakan taktik dari tuhan. Selain itu, Mereka tidak mempunyai inisiatif untuk melakukan pencegahan dan penanggulangnannya.

Bencana alam bisa terjadi melalui proses dan berlangsung secara perlahan-lahan sehingga bisa diramalkan serta bisa juga terjadi dengan tiba-tiba. Seperti halnya gempa bumi, hingga saat ini nyaris tidak dapat diprediksi dengan akurat dimana, kapan, dan berap kekuatan gempa bumi tersebut. Walaupun demikian dampak terjadinya gempa bumi dapat diminimalkan dengan membekali masyarakat kemampuan atau keterampilan bagaimana merespon bencana seperti keterampilan bagaimana meyelamatkan diri ketika terjadi gempa, dan meminimalisir kerentanan dampak bencana alam itu sendiri, seperti dibangunnya rumah tahan terhadap gempa dengan kekuatan tertentu.

$$
\text { Menurut Agustin }
$$

Bencana alam tersebut terjadi sebab faktor ancaman bertemu dengan faktor kerentanan dan ketidakmampuan atau kemampuan yang rendah untuk menanggapi ancaman itu, keduanya menyebabkan terganggunya kehidupan masyarakat seperti kerusakan rumah, hilanggnya harta benda serta korban jiwa. Umumnya bahaya bencana dapat terjadi di mana saja dengan sedikit atau tanpa peringatan, maka sangat penting agar siap siaga terhadap bahaya bencana untuk mengurangi risiko dampaknya (Yayasan Jambo Minda, 2010).

Pengetahuan dan pemahaman masyarakat tentang lingkungan setempat merupakan hal terpenting untuk meminimalisir kerentanan di masyarakat. Mitigasi bencana berbasis masyarakat bisa dengan memberdayakan anggota masyarakat agar dapat bekerjasama dalam membuat rencana stategis dan berguna bagi masyarakat. Masyarakat harus aktif dalam membanagun kembali lingkungannya sendiri, sebab yang memahami dan mengerti tentang 
kebutuhan yang terbaik adalah

IDEP, 2007).

masyarakat sendiri. Masyarakat yang menghadapi risiko bencana akan memperoleh manfaat dengan memahami apa yang harus dilakukan saat bencana terjadi (Yayasan IDEP, 2007)

Terdapat beberapa manfaat mitigasi bencana berbasis masyarakat diantanya adalah memberikan dan mengembangkan pengetahuan tentang mitigasi kepada masyarakat sehingga tingkat kewaspadaan mereka terhadap resiko dihadapi bisa meningkat, merangsang masyarakat supaya lebih siap dan tanggap dalam menghadapi bencana di lingkungannya dan membantu memahami dimana dan bagaimana bencana itu mungkin dapat terjadi, memperkuat dan meningkatkan kemampuan masyarakat dalam mengatasi bencana, contohanya membuat pererncanaan untuk jalur pengungsian dan menjalin sitergitas dengan lembaga-lembaga yang bisa membantu ketika terjadi bencana, membentuk kelompok masyarakat penanggulangan bencana, serta meningkatkan pemahaman dan kesadaran masyarakat mengenai lingkungan alam dan perannya dalam mengurangi risiko bencana (Yayasan

\section{KESIMPULAN}

Paradigma terhadap penanganan bencana ditingkat penduduk belum cukup banyak berubah. Masih banyak penduduk yang menganggap bahwa bencana itu merupakan suatu takdir. Hal ini merupakan gambaran bahwa paradigma konvensional masih kuat dan berakar di masyarakat. Pada umumnya masyarakat percaya bahwa bencana adalah balasan atas perbuatan dosa sehingga seseorang harus menerimanya sebagai takdir akibat perbuatannya dan mereka tidak mau lagi berusaha untuk mengambil langkah-langkah pencegahan atau penanggulangannya.

Pemetaan daerah rawan bencana, pembangunan sistem deteksi dini, dan pemanfaatan penataan ruang nasional merupakan langkah-langkah struktural dalam mitigasi bencana. Namun, ketiga kegiatan itu wajib memberikan ruang pada masyarakat untuk memberikan kontribusi dalam penyampaian informasi terkait daerah bencana dan juga sebagai penerima informasi terkait bencana dan cara untuk menghindari dampak dari bencna. Poin ketiga dari empat kebijakan di atas menunjukkan bahwa pentingnya peran masyarakat dalam usaha pengurangan 
Journal of Aquaculture Science

DOI: https://doi.org/10.31093/joas.v6i1IS.168

risiko bencana.

\section{Ucapan Terima Kasih}

Ucapan

terimakasih

disampaikan kepada sejawat yang telah memberikan berbagai batuan untuk penulisan ini baik masukan, saran, bacaan literatur. Terutama kepada pikah Universitas $17 \quad$ Agustus 1945 Banyuwangi yang telah memberi dukungan terhadap penelitian ini.

\section{DAFTAR PUSTAKA}

Agustin, H. (2014). Persepsi Masyarakat Kenagarian Sumani Tentang Kesiapsiagaan Bencana Gempa Bumi. Jurnal Kesehatan Komunitas, 2(5): 199206.

Badan Nasional Penanggulangan Bencana. (2007). Pengenalan Karakteristik Bencana dan Upaya Mitigasinya di Indonesia (II).

BNPB. (2014). Indeks Risiko Bencana Indonesia Tahun 2013.

Darsiharjo, M. S. (2005). Peran Pembelajaran Geografi Dalam Pembangunan Wilayah Rawan Bencana. File.Upi.Edu, 1-11.

Jokowinarno, D. (2011). Mitigasi Bencana Tsunami Di Wilayah Pesisir Lampung. Jurnal Rekayasa, 15(1): 13-20.
July 2021 Vol 6 Issue Spesial: 157-163

Online pada http://joas.co.id

Kementerian Kelautan dan Perikanan. (2019). Kementerian Kelautan dan Perikanan SIARAN PERS Nomor: SP204/SJ.04/VIII/2019.

Murdiaty, M., Angela, A., \& Sylvia, C. (2020). Pengelompokkan Data Bencana Alam Berdasarkan Wilayah, Waktu, Jumlah Korban dan Kerusakan Fasilitas Dengan Algoritma K-Means. JURNAL MEDIA INFORMATIKA BUDIDARMA, 4(3): 744-752.

Prayoga, D., Fatah, M. Z., Lailiyah, S., \& Sari, J. D. E. (2017). Tingkat Peran Serta Masyarakat Pada Tahap Pra Bencana Di Daerah Wisata Kabupaten Banyuwangi: Implementasi Perka BNPB No. 11 Tahun 2014. Jurnal Riset Kebencanaan Indonesia, Vol. 3(2): 73-78.

Priyowidodo, G., \& Luik, J. E. (2013). Literasi mitigasi bencana tsunami untuk masyarakat pesisir di Kabupaten Pacitan Jawa Timur. Ekotrans, 13(1): 47-61.

Undang-Undang Republik Indonesia. (2007). Undang-undang republik indonesia nomor 24 tahun 2007 tentang penanggulangan bencana.
Yayasan IDEP. (2007). Panduan Penanggulangan Bencana Berbasis Masyarakat.

Yayasan Jambo Minda. (2010). Panduan Pendidikan Penanggulangan Bencana Untuk Sekolah. 